\title{
CHARACTERISTICS AND OUTCOMES OF ANKLE INJURIES IN WINTER AND SUMMER SEASONS
}

\author{
Ruta Jakušonoka ${ }^{1, \#}$, Toms Arcimovič̌s ${ }^{2}$, Gunita Vinčela ${ }^{3}$, Andris Jumtiṇš ${ }^{1,4}$, \\ Ilze Čerṇavska ${ }^{4}$, and Zane Pavāre ${ }^{1,4}$ \\ ${ }^{1}$ Department of Orthopaedics, Rīga Stradiṇš University, 18 Duntes Str., Rīga, LV-1005, LATVIA \\ ${ }^{2}$ Faculty of Residency, Rīga Stradiṇš University, 16 Dzirciema Str., Rĩga, LV-1005, LATVIA \\ ${ }^{3}$ Faculty of Medicine, Rīga Stradinš̌ University, 16 Dzirciema Str., Rīga, LV-1005, LATVIA \\ ${ }^{4}$ Hospital of Traumatology and Orthopaedics, 22 Duntes Str., Rīga, LV-1005, LATVIA \\ \# Corresponding author: ruta.jakusonoka@ rsu.Iv
}

Communicated by Dainis Krieviṇš

\begin{abstract}
The diagnostics and treatment of ankle trauma remain challenging as they enable the patients' return to work and ability to perform daily activities. The aim of the study was to evaluate characteristics and outcomes of ankle injuries, focusing on the trauma mechanisms in winter and summer seasons. A retrospective study was conducted of 182 patients with ankle injuries, admitted to the Hospital of Traumatology and Orthopaedics in 2014, 2015, and 2016 from the months December to February, and from June to August. Patients with supination-external rotation (SER) type ankle injuries were included in the functional outcome evaluation. Our results suggested that most of the injuries were SER type, stage IV in both seasons, and that more than $2 / 3$ of the SER type ankle injuries that needed surgery were in the winter season. In patients with tibiofibular syndesmosis (TFS) rupture the functional results were worse than in those without TFS rupture, but in winter and summer seasons they seemed to be without statistical difference.
\end{abstract}

Key words: seasonal ankle injuries, supination-external rotation, tibiofibular syndesmosis injuries.

\section{INTRODUCTION}

Complex ankle injuries include ankle fractures. Ankle fractures currently account for nine percent of fractures, and incidence and severity are increasing (Tartaglione et al., 2015). Approximately one in seven ankle fractures are associated with an injury to the tibiofibular syndesmosis (TFS) (Hunt, 2013). The diagnostics and treatment of ankle trauma, including TFS injuries, remain challenging.

In clinical practice, ankle fractures have three classifications: Danis-Weber classification, AO classification and Lauge-Hansen classification. Every classification system for ankle fractures is designed to help the surgeon to decide on appropriate treatment, assessment of the prognosis and all of the classification systems can be used as guide for the neccesary treatment (Karlsson et al., 2013).

Danis-Weber classification proposed the system based on the localisation of the main fibular fracture line, dividing fractures into three groups: type A (below the TFS level), type B (at the TFS level), and type C (above the TFS level). Nevertheless, this classification does not consistently predict the extent of the injury in the TFS and other structures (da Fonseca et al., 2017).

AO/OTA classification expanded the Danis-Weber classification and takes into account the fibular fracture level in relation to the TFS, the location of the fracture lines, degree of comminution and damage to other structures (Buckley et al., 2017).

Lauge-Hansen classification is based on foot position at the time of the traumatic event (supination or pronation) and the direction of the deforming forces (abduction, adduction, or external rotation). This classification was created in 1942 by Lauge-Hansen and was the first modern classification system for fractures related to the ankle. The classification is used to diagnose ankle injuries in context with the trauma mechanism and types of ankle injuries are subdivided into 
stages of increasing severity (Browner et al., 2015, pp. 2189-2250; Boszczyk et al., 2018). Supination-external rotation (SER) type injuries account for most of all ankle fractures $-40 \%$ to $75 \%$ of ankle fractures, pronation-external rotation (PER) type fractures - 5\% to $20 \%$, pronation-abduction (PA) type $-5 \%$ to $20 \%$, and supination-adduction (SA) type fractures - 5\% to 20\% (Egol et al., 2015).

We used Lauge-Hansen classification in our study to evaluate seasonal characteristics of ankle injuries, based on the mechanism of the trauma.

Patients' evaluation with SER type injury traumatic TFS damage is a topical issue, because 50 percent of SER type (Danis-Weber B type) fractures are associated with TFS injury. To determine if TFS damage is radiologically detectable, tibiofibular clear space (TFCS) measurement is used (Hermans et al., 2010).

Anatomical reduction of the fibula in the fibular notch of the tibia and fixation of TFS in case of its rupture is important to restore a talocrural joint (Pallis et al., 2018). The functional outcome and quality of patients' life mostly depend on this.

For the assessment of functional outcome in patients after ankle injuries, the Foot and Ankle Disability Index (FADI) is used (Martin et al., 1999). Using FADI activities involving ankle joint, functional impairments can be identified, future treatment planned, rehabilitation measures and their effectiveness evaluated.

Higher magnitude of forces deforming the bone during trauma can cause more severe fracture patterns (Obrant, 2000, pp. 309-312; Lerner and Solomin, 2012). Seasonal characteristics of ankle injuries are important, because slipping on ice related ankle injuries in winter and twisting ankle injuries in summer can be caused by different positioning of the foot at time of injury, difference in trauma mechanisms and directions of deforming forces, and the magnitude of loading can be higher in winter than in summer.

The aim of the study was to evaluate characteristics and outcomes of ankle injuries, focusing on the trauma mechanism in summer and winter seasons.

\section{MATERIAL AND METHODS}

Patient selection. Retrospective material analysis of 182 patients with ankle injuries treated in the Hospital of Traumatology and Orthopedics in 2014, 2015, 2016 during time periods of December to February and from June to August was performed using hospital case-records. December, January and February were chosen as the time period for the winter season and June, July and August were chosen as the months of the summer season. Patients were included in the study if they had low-energy ankle injury and were treated surgically. Low-energy injury was defined as a twisted an$\mathrm{kle}$, or fall from a standing height or low height $(<1 \mathrm{~m})$
(Zhu et al., 2020). Inclusion criteria of patients in the winter season were information in the patients' case-record about slipping on ice injury. Ankle fractures were classified according to the Lauge-Hansen classification by using patients' preoperative radiographs.

The inclusion criteria in the study for the functional outcome evaluation were patients with SER type injuries, 18 to 65 years of age, and both sexes. Patients who were missing in follow-up or had a history of another trauma of lower extremities after ankle trauma, were excluded from the functional outcome analysis. Figure 1 shows the flowchart of patient selection.

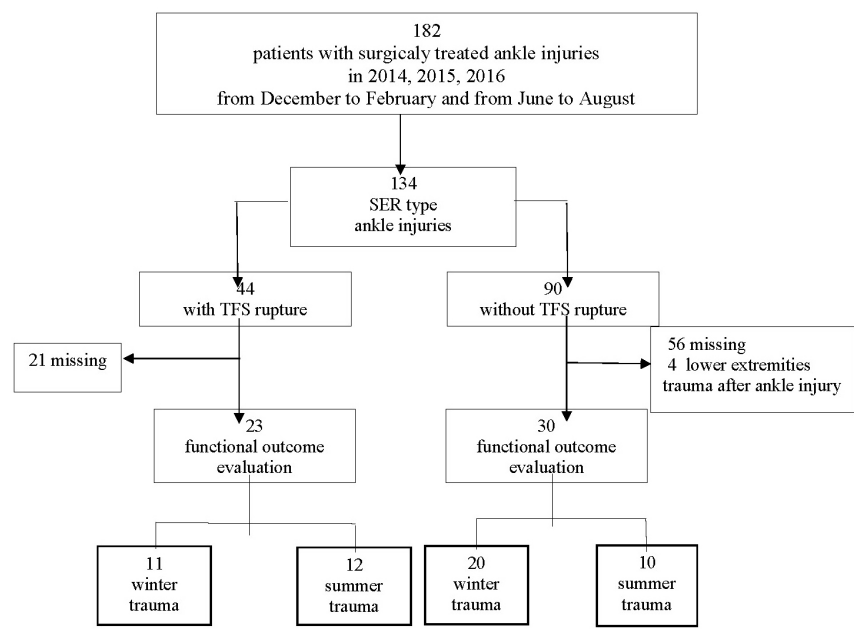

Fig. 1. Flowchart of the patient selection; SER, supination-external rotation; TFS, tibiofibular syndesmosis.

Evaluation methods. For the radiological assessment, preoperative, postoperative and follow-up anteroposterior and lateral radiographs were evaluated by a radiologist experienced in musculoskeletal radiology. The TFCS measurement was used to determine if TFS was radiologically detectable. A TFCS greater than $5 \mathrm{~mm}$ was considered as TFS injury (Hermans et al., 2012; Egol et al., 2015). The TFCS measurement after TFS surgery presented the possibility to more accurately assess the anatomical reduction of the fibula in the fibular notch of the tibia. The TFCS measurement was performed in the anteroposterior radiograph (Fig. 2).

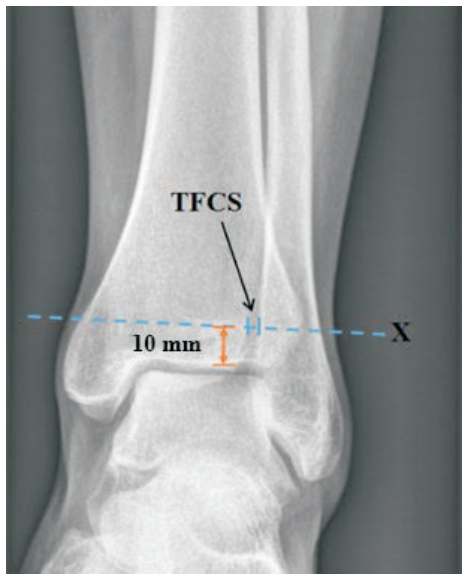

Fig. 2. Measurement of the tibiofibular clear space (TFCS) in the anteroposterior radiograph of the ankle between the lateral border of the anterolateral tibial tubercle (TillouxChaput tubercle) and the medial border of fibula at $10 \mathrm{~mm}$ above and parallel to the tibial plafond (line $\mathrm{X}$ ). 
The decision about treatment of a ankle injury was made taking into account the findings of the clinical examination, standard anteroposterior and lateral radiographs. The treatment algorithm was based on restoring normal ankle joint anatomy, providing stability for early movement. Stable and undisplaced ankle fractures were treated conservatively. Unstable and displaced ankle fractures were treated by open reduction and internal fixation. Nevertheless, decision to perform surgery and the surgical method was based on the trauma mechanism and soft tissue condition, as well as patient age and comorbidities. In our hospital, if TFS injury requires fixation, we use surgery with fibulotibial syndesmotic position screw (FTSPS) fixation, which is a standard method for TFS fixation. The syndesmotic instability during surgery is checked using a bone hook test.

Patients were given spinal anaesthesia and they were placed on a radiolucent operating table in a supine position. A pneumatic tourniquet was used. A longitudinal incision was performed along the posterior margin of the fibula. The lateral malleolar fracture was reduced and fixed with a nonlocking semi-tubular plate. Open reduction and internal fixation of the medial malleolar fracture were then performed using a cancellous screw and K-wire. The decision about the stability of the TFS was made after its evaluation intraoperatively. The fibula was grasped with a bone hook and gently pulled posterolaterally to reveal any significant residual tibiofibular instability. If the stability was insufficient, one $3.5 \mathrm{~mm}$ FTSPS in the semi-tubular plate, $2 \mathrm{~cm}$ proximal to the tibial plafond was inserted while the fibula was held in its anatomical relation to the tibia. The length of this screw was chosen to pass through the TFS and not to pass through the medial tibial cortex (Buckley et al., 2017).

The functional outcome of patients with SER type injuries was evaluated 16-37 months after the trauma. The patients were recruited for the evaluation of functional outcome. Those who did not respond to three phone calls and/or the invitation letter, refused to participate in the study or had history of another trauma of lower extremities after ankle trauma, were excluded. The patients' complaints, functional and radiological assessment were included in the evaluation of outcomes. One group was comprised of patients who had TFS rupture and had undergone surgery with FTSPS fixation, and the second group were patients without TFS rupture and who had undergone surgery without FTSPS fixation.

The patients' complaints were evaluated and functional assessment was performed based on 26 criteria according to the FADI scale for grading the foot and ankle disability. Activities on this scale are arranged from 0 to 4 points according to the level of difficulty to perform activities: no difficulty at all (4 points), slight difficulty (3 points), moderate difficulty ( 2 points), extreme difficulty ( 1 point), unable to do the activities (0 points) (Hale et al., 2005). The points obtained were analysed in both groups. The FADI scores were calculated in percentage terms and the difference between the mean FADI scores between the two groups was determined.
The FADI scores in patients who had TFS rupture were compared with the width of the TFCS in the postoperative anteroposterior radiographs. The preoperative TFCS and FADI scores for these patients were compared between summer and winter season trauma.

The study was permitted by the Ethics Commision of the Hospital of Traumatology and Orthopedics (Nr. 7, 24.03.2017).

Statistical analysis. The statistical analysis was performed with SPSS software version 20.00 or data was evaluated in percentages, as appropriate. The FADI points and scores were expressed as mean \pm standard deviation. A Kolmogorov-Smirnov test was used to detect normality of data distribution. A Student's t-test was used for the FADI mean points and mean scores comparison between both groups. A nonparametric Mann-Whitney test for two independent samples was used for comparing TFCS in winter and summer season in patients who had TFS rupture. The Pearson test was used to determine correlation between FADI scores and width of the TFCS in patients who had TFS rupture. A $p$-value $<0.05$ was considered statistically significant.

\section{RESULTS}

The retrospective study included 182 patients admitted in the hospital with ankle injuries. Ankle injuries were evaluated according to Lauge-Hansen classification. In our study $134(74 \%)$ patients had SER type, $28(15 \%)$ patients PER type, 13 (7\%) patients - PA type and 7 (4\%) patients - SA type injuries.

From the study material, $123(67.6 \%)$ patients had winter season and $59(32.4 \%)$ patients had summer season injuries. Distribution of patient frequency admitted in the hospital with ankle injuries according to the trauma mechanism between winter and summer seasons is summarised in Figure 3.

The summary of types and stages of ankle injuries and their seasonal characteristics in our study are summarised in Table 1.

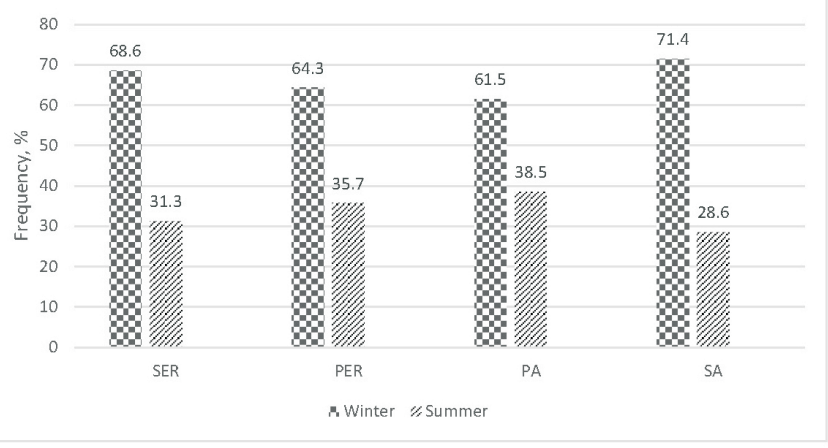

Fig. 3. Patients frequency with ankle injuries, admitted to the hospital, according to the trauma mechanisms between winter and summer season; SER, supination-external rotation; PER, pronation-external rotation; PA, pronation-abduction; SA, supination-adduction. 
Table 1. Ankle injuries types and stages

\begin{tabular}{|c|c|c|c|c|}
\hline \multirow[t]{2}{*}{ Injury type } & \multicolumn{4}{|c|}{ Injury stage } \\
\hline & $\mathrm{I}, \mathrm{n}$ & II, $\mathrm{n}$ & III, n & IV, $n$ \\
\hline \multicolumn{5}{|l|}{ SER } \\
\hline Winter $\mathrm{n}=92(68.6 \%)$ & 0 & 15 & 15 & 62 \\
\hline Summer $n=42(31.3 \%)$ & 0 & 7 & 5 & 30 \\
\hline \multicolumn{5}{|l|}{ PER } \\
\hline Winter $\mathrm{n}=18(64.3 \%)$ & 2 & 1 & 9 & 6 \\
\hline Summer $\mathrm{n}=10(35.7 \%)$ & 3 & 0 & 2 & 5 \\
\hline \multicolumn{5}{|l|}{ PA } \\
\hline Winter $\mathrm{n}=8(61.5 \%)$ & 1 & 2 & 5 & - \\
\hline Summer $\mathrm{n}=5(38.0 \%)$ & 1 & 2 & 2 & - \\
\hline \multicolumn{5}{|l|}{ SA } \\
\hline Winter $\mathrm{n}=5(71.4 \%)$ & 3 & 2 & - & - \\
\hline Summer $n=2(28.0 \%)$ & 2 & 0 & - & - \\
\hline
\end{tabular}

SER, supination-external rotation; PER, pronation-external rotation; PA, pronation-abduction; SA, supination-adduction; -, no stage; $n$, the number of patients in the group.

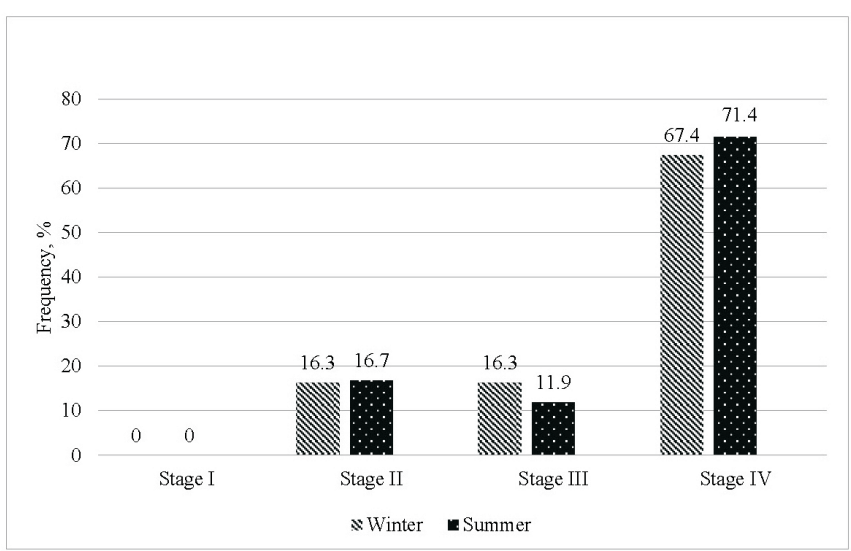

Fig. 4. Supination-external rotation (SER) type injuries, stages I, II, III, IV frequency according to the Lauge-Hansen clasification in winter and summer seasons.

Of 134 patients with SER type ankle injuries, 44 patients had TFS rupture and had undergone surgery with FTSPS fixation, and 90 patients did not have TFS rupture. The frequency of stages of SER type injuries in winter and summer seasons are shown in Figure 4.

Furthermore we evaluated medium-term outcomes in 53 patients with SER type injuries 16-37 months after the trauma who met the inclusion criteria. There were 23 patients (14 women and 9 men), mean age 50.8, with TFS rupture; and 30 patients (23 women, 7 men), mean age 48.7, without TFS rupture.

Patients with TFS rupture had a mean FADI score $91.80 \pm$ 8.99 (65.38-100); patients without TFS rupture had a mean FADI score $95.90 \pm 6.27(68.27-100)(p=0.017)$.

Eleven patients with TFS rupture had SER type stage III injuries, and 12 patients had SER type stage IV injuries. Nine patients had posterolateral corner fractures less than 25 percent of the articular surface on the lateral radiograph, and none of them were fixated. In this group in the preoperative anteroposterior radiograph the TFCS was from 2.50 to
Table 2. Mean points of the FADI scale activities in the group of patients with TFS rupture and group of patients without TFS rupture

\begin{tabular}{|c|c|c|c|}
\hline \multirow[t]{2}{*}{ FADI scale activities } & $\begin{array}{l}\text { Group of } \\
\text { patients with } \\
\text { TFS rupture } \\
\quad(\mathrm{n}=23)\end{array}$ & $\begin{array}{c}\text { Group of } \\
\text { patients } \\
\text { without TFS } \\
\text { rupture }(n=30)\end{array}$ & \multirow[t]{2}{*}{$p$ value } \\
\hline & Mean (points) & Mean (points) & \\
\hline 1. Standing & 3.91 & 3.97 & 0.26 \\
\hline 2. Walking on even ground & 3.78 & 3.90 & 0.15 \\
\hline $\begin{array}{l}\text { 3. Walking on even ground with- } \\
\text { out shoes }\end{array}$ & 3.61 & 3.87 & 0.04 \\
\hline 4. Walking up hills & 3.57 & 3.70 & 016 \\
\hline 5. Walking down hills & 3.57 & 3.67 & 0.26 \\
\hline 6. Going upstairs & 3.17 & 3.57 & 0.01 \\
\hline 7. Going downstairs & 3.39 & 3.77 & 0.02 \\
\hline 8. Walking on uneven ground & 3.61 & 3.87 & 0.09 \\
\hline 9. Stepping up and down curves & 3.48 & 3.73 & 0.12 \\
\hline 10. Squatting & 2.83 & 3.40 & 0.03 \\
\hline 11. Sleeping & 3.96 & 3.97 & 0.85 \\
\hline 12. Coming up to your toes & 3.13 & 3.50 & 0.17 \\
\hline 13. Walking initially & 4.00 & 3.97 & 0.38 \\
\hline 14. Walking 5 minutes or less & 4.00 & 4.00 & 1.0 \\
\hline $\begin{array}{l}\text { 15. Walking approximately } 10 \\
\text { minutes }\end{array}$ & 4.00 & 3.97 & 0.38 \\
\hline 16. Walking 15 minutes or more & 3.74 & 3.93 & 0.12 \\
\hline 17. Home responsibilities & 3.96 & 3.97 & 0.85 \\
\hline 18. Activities of daily living & 3.83 & 3.93 & 0.30 \\
\hline 19. Personal care & 3.87 & 3.97 & 0.19 \\
\hline $\begin{array}{l}\text { 20. Light to moderate work } \\
\text { (standing, walking) }\end{array}$ & 3.83 & 3.97 & 0.15 \\
\hline $\begin{array}{l}\text { 21. Heavy work (push/pulling, } \\
\text { climbing, carrying) }\end{array}$ & 3.35 & 3.60 & 0.21 \\
\hline 22. Recreational activities & 3.70 & 3.97 & 0.01 \\
\hline 23. The general level of pain & 3.78 & 3.93 & 0.19 \\
\hline 24. Pain at rest & 3.87 & 3.97 & 0.22 \\
\hline $\begin{array}{l}\text { 25. Pain during your normal ac- } \\
\text { tivities }\end{array}$ & 3.61 & 3.80 & 0.38 \\
\hline 26. Pain first thing in the morning & 4.00 & 3.97 & 0.26 \\
\hline
\end{tabular}

$\mathrm{n}$, the number of patients in the group; TFS, tibiofibular syndesmosis; FADI, the Foot and Ankle Disability Index.

$11.39 \mathrm{~mm}$, mean $5.47 \pm 2.24 \mathrm{~mm}$; in the postoperative anteroposterior radiographs the TFCS was from 1.12 to 9.94 $\mathrm{mm}$, mean $3.20 \pm 2.98 \mathrm{~mm}(p=0.20)$. There was a moderate negative correlation between FADI score and TFCS (rs $=-0.61347, p=0.001)$.

During evaluation of functional results, in 14 patients FTSPS had been removed, in six patients all implants had been removed, and in three patients no implants had been removed.

The mean points of the FADI scale in patients with TFS rupture were low in the following aspects: walking on even ground without shoes, walking up stairs, walking down stairs, squatting and recreational activities (Table 2). 
From those patients who had TFS rupture, eleven patients had winter season ice-related trauma and 12 patients had summer season trauma. In the preoperative anteroposterior radiograph in winter trauma, the TFCS was from 3.74 to $9.03 \mathrm{~mm}$, mean $6.32 \pm 1.72 \mathrm{~mm}$; in summer trauma - from 2.50 to $11.39 \mathrm{~mm}$, mean $4.68 \pm 2.42 \mathrm{~mm}(p=0.019)$. In the postoperative anteroposterior radiograph in winter trauma, the TFCS was from 1.32 to $9.94 \mathrm{~mm}$, mean $3.97 \pm 2.41$ $\mathrm{mm}$; in summer trauma - from 1.12 to $6.26 \mathrm{~mm}$, mean $2.75 \pm 1.33 \mathrm{~mm}(p=0.176)$. The mean FADI score in the group with TFS rupture in winter was $91.43 \pm 9.83$ (65.38-100); the mean FADI score in summer was $92.22 \pm$ $8.14(75-100)(p=0.926)$.

From those patients without TFS rupture, 20 patients had winter season ice-related trauma and ten patients had summer season trauma. The mean FADI score in this group in winter was $97.49 \pm 3.45(90.38-100)$; the mean FADI score in summer was $92.98 \pm 9.33(68.27-100)(p=0.061)$.

\section{DISCUSSION}

The goal of the diagnostics and surgical treatment of patients with ankle injuries is to achieve functional outcome. The seasonal and weather characteristics of ankle trauma are described in the literature. More ankle fractures are reported due to a fall in winter than in spring and summer (Wynkoop et al., 2017; Shukla et al., 2018). This was also found in our study. Literature also points out that weather and seasonal variations of ankle injuries are important, as they account for the major part of all trauma patients admitted in the hospital, especially in the winter season, and thus affect hospital resources; this data could be useful for determining staffing requirements and resource allocation (Rising et al., 2006; Friede et al., 2009).

Our research analysed the characteristics and outcomes of ankle injuries caused by different trauma mechanisms in winter and summer seasons. The percentage of SER, PER and PA types of ankle injuries according to Lauge-Hansen classification in our study was in line with the frames reported in literature, but we also established that in the first place percentage-wise were SER type injuries, and in second place - PER type injuries in both seasons, in winter season accouting for approximately $2 / 3$ more of these injuries. These results seem to highlight a tendency that the dominating direction of the deforming force is external rotation, in both winter and summer seasons. Supinationexternal rotation type stage IV injuries were approximately twice more prominent in the winter season, with more ankle anatomical structures involved than in summer season.

Supination-adduction type injuries were less than Egol et al., 2015 reported. Our results show more severe injuries in winter than in summer, which can point to higher loading magnitude during trauma in winter than in summer.

Using Lauge-Hansen classification in the context of the trauma mechanism in the evaluation of ankle injuries, we were able to predict injuries that could not be clearly visible in radiographs and suggested the need for additional imaging, thus it being essential in the diagnostics and preparation for the appropriate surgical treatment.

We evaluated the outcomes of patients with TFS rupture and FTSPS fixation in the context of season, as the treatment and outcomes of these ankle injuries are more controversial. The TFS is critical for maintaining the stability of ankle mortise, holding together distal tibia and fibula with four ligaments: anterior-inferior tibiofibular ligament, posterior-inferior tibiofibular ligament, inferior transverse tibiofibular ligament and interosseous ligament. Tibiofibular syndesmosis rupture involves the full extent of interosseous ligament and the ankle mortise is unstable (Thompson et al., 2009).

Patients were evaluated 1-3 years after surgery, because some studies showed that in most cases the functional outcome one year after trauma did not change significantly and evaluation in the medium-term after trauma gave a possibility to treat the pathology if found (Castillo et al., 2011; Lennquist, 2012). We used FADI score for the evaluation of functional outcome, as it shows criteria reflecting patients ability to perform everyday activities and work.

We compared our patients' outcomes with those in literature data, with ankle injuries and TFS rupture, operated by using FTSPS fixation. The research described in literature shows that horizontal distance between the medial cortical border of fibula and radiodense line of the tibiofibular notch $1 \mathrm{~cm}$ above the ankle joint was measured between 3 and 13 $\mathrm{mm}$ with a $7.1 \mathrm{~mm}$ average value preoperatively and between 2 and $6 \mathrm{~mm}$ with a $3.6 \mathrm{~mm}$ average value postoperatively (Sipahioglu et al., 2018). In our study, the mean TFCS was $5.47 \mathrm{~mm}$ in the preoperative anteroposterior radiographs, and $3.20 \mathrm{~mm}$ in the postoperative anteroposterior radiographs.

Patients who had suffered from SER type ankle injuries without TFS rupture had better medium-term functional outcome than patients with TFS rupture and FTSPS fixation.

In an other study, the outcome evaluation mean FADI score was 93.13 in simple ankle fractures (without TFS rupture) (Sharma et al., 2016).

Narrow TFCS significantly correlated with high FADI scores due to the anatomical reduction of the fibula in the level of TFS for the functional outcome after ankle injuries with TFS rupture.

We did not divide patients into groups according to the FTSPS removal, because in the patient group with TFS rupture, FTSPS had been removed in more than $2 / 3$ of patients during functional outcome evaluation, all implants had been removed in approximately $1 / 3$ patients and no implants had been removed in only 3 patients. Research has shown no statistical difference in the clinical outcome of patients who 
had their FTSPS removed and those who had not (Hamid et al., 2009)

Naqvi et al. performed a study to assess the outcome after FTSPS fixations with a follow-up of 2.5 years. Regarding the clinical outcome, these patients showed a mean FADI score of 81.22 (Naqvi et al., 2012). In our study the mean FADI score was 91.80 in patients who had TFS rupture.

One patient had unsatisfactory syndesmotic reduction - the TFCS after surgery was $9.94 \mathrm{~mm}$, and the patient had a FADI score of 65.38 in the follow-up.

Studies have shown that TFS rupture leads to a significant restriction in dorsiflexion in the ankle joint (Manjoo et al., 2010; Kohake et al., 2019). The mentioned literature data support our findings, because in our study of patients with TFS rupture the most difficult was walking on even ground without shoes, walking up stairs, walking down stairs, squatting and recreational activities that demand dorsiflexion in the ankle joint. Taking into account the findings in the examination by using the FADI scale, early rehabilitation measures are recommended for these patients to improve the range of the ankle dorsiflexion and activities demanding this movement.

This study highlights the characteristics and outcomes of ankle injuries caused by different trauma mechanisms and energy in winter and summer seasons, as well as the necessity of planning of hospital resources. We recommend careful evaluation of the ankle injuries using Lauge-Hansen classification since the injury type is essential in the diagnostics and preparation of the appropriate surgical treatment.

\section{CONCLUSIONS}

The findings in our study show that more than $2 / 3$ of the ankle injuries of all types, according to the Lauge-Hansen classification, which needed surgery, were in the winter season.

In patients who underwent surgery, approximately $2 / 3$ SER type injuries occurred in winter and approximately $1 / 3$ SER type injuries in summer season. Supination-external rotation type stage IV injuries were contributed approximately $2 / 3$ of all SER type injuries in both seasons.

In the radiological results, mean TFCS in the preoperative radiograph in winter was larger than in summer injuries, but in the postoperative radiograph there was not any statistical difference in injuries between both seasons.

In comparing of patients who had SER type ankle injuries with TFS rupture, and without TFS rupture - in patients with TFS rupture the functional results were worse, but without statistical difference between winter and summer seasons.

Limitation of the study. Due to the relatively small number of SER type ankle injury patients with FTSPS fixa- tion and seasonal injuries, our results should be taken cautiously. Further studies on larger patients groups will be needed to confirm the results.

\section{REFERENCES}

Boszczyk, A., Fudalej, M., Kwapisz, S., Błoński, M., Kiciński, M., Kordasiewicz, B., Rammelt, S. (2018). X-ray features to predict ankle fracture mechanism. Forensic Sci. Int., 291, 185-192.

Browner, B. D., Jupiter, J. B., Krettek, C., Anderson P. A. (2015). Skeletal Trauma. $5^{\text {th }}$ ed. W. B. Saunders, Philadelphia. 2704 pp.

Buckley, R. E., Moran, C. G., Apivatthakakul, T. (2017). AO Principles of Fracture Management. $3^{\text {rd }}$ ed. AO Foundation, Switzerland, 933-955 pp.

Castillo, R. C., MacKenzie, E. J., Bosse, M. J., LEAP Study Group. (2011). Orthopaedic trauma clinical research: Is 2-year follow up necessary? Results from a longitudinal study of severe extremity trauma. J. Trauma, $\mathbf{7 1}$ 1726-1731.

da Fonseca, L. L., Nunes, I. G., Nogueira, R. R., Vieira Martins, G. E; Mesencio, A. C., Kobata, S. I. (2017). Reproducibility of the LaugeHansen, Danis-Weber, and AO classifications for ankle fractures Rev. Bras. Ortop., 53 (1), 101-106.

Egol, K., Koval, K., Zuckerman, J. (2015). Handbook of Fractures. $5^{\text {th }}$ ed Wolters Kluwer Health, Philadelphia, pp. 465-469.

Friede, K. A., Osborne, M. C., Erickson, D. J., Roesler, J. S., Azam, A., Croston, J. K., McGonigal, M. D., Ney, A. L. (2009). Predicting trauma admissions: The effect of weather, weekday, and other variables. Minn. Med., 92 (11), 47-49.

Hale, S. A., Hertel, J. (2005). Reliability and sensitivity of the Foot and Ankle Disability Index in subjects with chronic ankle instability. J. Athl. Train., 40, 35-40.

Hamid, N., Loeffler, B. J., Braddy, W., Kellam, J. F., Cohen, B. E., Bosse, M. J. (2009). Outcome after fixation of ankle fractures with an injury to the syndesmosis: The effect of the syndesmosis screw. J. Bone Joint Surg. Br., 91, 1069-1073.

Hermans, J. J., Beumer, A., de Jong, T. A., Kleinrensink, G. J. (2010). Anatomy of the distal tibiofibular syndesmosis in adults: A pictorial essay with a multimodality approach. J. Anat., 217, 633-645.

Hermans, J. J., Wentink, N., Beumer, A., Hop, W. C., Heijboer, M. P., Moonen, A. F., Ginai, A. Z. (2012). Correlation between radiological assessment of acute ankle fractures and syndesmotic injury on MRI. Skeletal Radiol., 41, 787-801.

Hunt, K. J. (2013). Syndesmosis injuries. Curr. Rev. Musculoskelet. Med., 6, 304-312.

Karlsson, J., Brandsson, S., Möller, M. (2000). Ankle Fractures. In: Obrant, K. (Ed.) Management of Fractures in Severely Osteoporotic Bone. Springer, London, pp. 25-26.

Kohake, M. B. J., Wiebking, U., O'Loughlin, P. F., Krettek, C., Gaulke, R. (2019). Mid- to long-term outcomes after Weber B-type ankle fractures with and without syndesmotic rupture. In Vivo, 33, 255-261.

Lennquist, S. (Ed). (2012). Medical Response to Major Incidents and Disasters. Springer-Verlag, Berlin, Heidelberg. 359 pp.

Lerner, A., Solomin L. N. (2012). Open fractures. In: Solomin L. N. (Ed.) The Basic Principles of External Skeletal Fixation Using the Ilizarov and Other Devices. Springer-Verlag, 507-533 pp.

Manjoo, A., Sanders, D. W., Tieszer, C., MacLeod, M. D. (2010). Functional and radiographic results of patients with syndesmotic screw fixation: Implications for screw removal. J. Orthop. Trauma, 24, 2-6.

Martin, R. L., Burdett, R. G., Irrgang J. J. (1999). Development of the Foot and Ankle Disability Index (FADI). J. Orthop. Sports Phys. Ther., 29, $32-33$.

Naqvi, G. A., Cunningham, P., Lynch, B., Galvin, R., Awan, N. (2012). Fixation of ankle syndesmotic injuries: Comparison of tightrope fixation and 
syndesmotic screw fixation for accuracy of syndesmotic reduction. Amer. J. Sports Med., 40, 2828-2835.

Obrant, K. (Ed). (2000). Management of Fractures in Severely Osteoporotic Bone. Springer, London. 604 pp.

Pallis, M. P., Pressman, D. N., Heida, K., Nicholson, T., Ishikawa, S. (2018). Effect of ankle position on tibiotalar motion with screw fixation of the distal tibiofibular syndesmosis in a fracture model. Foot Ankle Int., 39, 746-750

Rising, W. R., O'Daniel, J. A., Roberts, C. S. (2006). Correlating weather and trauma admissions at a level I trauma center. J. Trauma, 60 (5), 1096-1100.

Sharma, G. K., Dhillon, M. S., Dhatt, S. S. (2016). The influence of foot and ankle injury patterns and treatment delays on outcomes in a tertiary hospital; a one-year prospective observation. Foot (Edinb.), 26, 48-52.

Shukla, R., Jain, N., Agarwal, U., Sheikh, T., Jain, R. (2018). Seasonal variation in orthopedic trauma patients - an experience from central India. $J$. Clin. Orthop. Trauma, 9, 40-43.
Sipahioglu, S., Zehir, S., Isikan, U. E., Niger J. (2018). Syndesmotic screw fixation in tibiofibular diastasis. Clin. Pract., 21, 692-697.

Tartaglione, J. P., Rosenbaum, A. J., Abousayed, M., DiPreta J. A. (2015) Classifications in brief: Lauge-Hansen classification of ankle fractures. Clin. Orthop. Relat. Res., 473, 3323-3328.

Thompson, J. C. (2009). Netters Concise Orthopaedic Anatomy. $2^{\text {nd }}$ ed. W. B.Saunders, Philadelphia. 349 pp.

Zhu, Y., Chen, W., Xin, X. E, Yin, Y., Huhu, C., Zhu, J., Zhang, J., Ye, F., Chen, A., Wu, Z., Ma, Z. (2020). Epidemiologic characteristics of traumatic fractures in elderly patients during the outbreak of coronavirus disease 2019 in China. Int. Orthop. Available at:

https://www.ncbi.nlm.nih.gov/pmc/articles/PMC7190279/ (accessed 25.07.2020).

Wynkoop, A., Ndubaku, O., Walter, N., Atkinson, T. (2017). Temporal variation in ankle fractures and orthopedic resident program planning in an urban level 1 trauma center. J. Foot Ankle Surg., 56 (4), 724-729.

Received 4 November 2019

Accepted in the final form 26 June 2020

\section{PĒDAS LOCĪTAVAS TRAUMU ZIEMAS UN VASARAS SEZONĀLĀS ĪPATNĪBAS UN REZULTĀTI}

Pēdas locītavas traumu ārstēšana joprojām ir izaicinājums, jo no tās rezultāta ir atkarīgs, cik labi pacients spēs veikt ikdienas aktivitātes un kad atgriezīsies darbā. Darba mērḳis bija novērtēt pacientiem pēdas locītavas traumu îpatnības un rezultātus saistībā ar traumas mehānismu ziemas un vasaras sezonā. Veikta retrospektīvā materiāla analīze 182 pacientiem ar pēdas locītavas traumām, kuri 2014., 2015., 2016. gadā no decembra līdz februārim un no jūnija līdz augustam ārstējušies Traumatoloğijas un ortopēdijas slimnīcā. Funkcionālā rezultāta novērtēšanā iekḷauti pacienti, kuriem bija supinācijas-ārējās rotācijas (SĀR) izraisītas traumas ar tibiofibulāāās sindesmozes (TFS) bojājumu un bez TFS bojājuma. Pētījuma rezultāti parāda, ka lielākā dạ̣a bija SĀR tipa izraisīti IV pakāpes bojājumi abās sezonās, vairāk kā 2/3no pēdas locītavas traumām, kuras ārstē kirurğiski, notika ziemā. Funkcionālie rezultāti pacientiem ar TFS bojājumu bija sliktāki nekā pacientiem bez TFS bojājuma, bet bez sezonālās atšķirības. 